$1-1-1961$

\title{
Factors influencing the yield and quality of sorgo sirup produced in West Virginia
}

\author{
M. W. Johnson \\ Charles B. Sperow \\ G. A. McLaren
}

Follow this and additional works at: https://researchrepository.wvu.edu/ wv_agricultural_and_forestry_experiment_station_bulletins

\section{Digital Commons Citation}

Johnson, M. W.; Sperow, Charles B.; and McLaren, G. A., "Factors influencing the yield and quality of sorgo sirup produced in West Virginia" (1961). West Virginia Agricultural and Forestry Experiment Station Bulletins. 450.

https://researchrepository.wvu.edu/wv_agricultural_and_forestry_experiment_station_bulletins/425 @ WVU. It has been accepted for inclusion in West Virginia Agricultural and Forestry Experiment Station Bulletins by an authorized administrator of The Research Repository @ WVU. For more information, please contact ian.harmon@mail.wvu.edu. 
Digitized by the Internet Archive in 2010 with funding from Lyrasis Members and Sloan Foundation 
Factors Influencing the Yield and Quality of Sorgo Sirup Produced in West Virginia 


\section{Summary}

Performance trials of sorgo cane were conducted in West Virginia at the Ohio Valley Sub-station in 1956, 1957, and 1958. Cane and sirup yields were obtained for each year, and in 1958 sugar analyses were made on the juice from six varieties of sorgo cane harvested at two stages of maturity and held from zero to 10 days before extracting the juice. The result of these analyses indicate the following:

1. Williams and Honey yielded juices with the best sugar balances and the largest amount of finished sirup per acre, 153.7 and 151.9 gallons, respectively.

2. Growth of the cane for 10 days beyond the soft-dough stage resulted in decreased total sugar content of the juice of five of the six varieties of sorgo cane studied.

3. Holding the harvested cane for 10 days before extracting the juice resulted in complete inversion of the sucrose of the juice of five of the six varieties. Presumably the invertase content of Brawley is quite low.

\section{THE AUTHORS}

M. W. Johnson is Associate Agronomist, C. B. Sperow is Assistant Agronomist, and G. A. McLaren is Agricultural Biochemist at the West Virginia University. Agricultural Experiment Station.

WEST VIRGINIA UNIVERSTTY Agricultural Experiment Station College of Agriculture, Forestry, and Home Economics A. H. Vanlandingham, Director MORGANTOWN 


\section{Factors Influencing the Yield and Quality of Sorgo Sirup Produced in West Virginia}

\section{Introduction}

M. W. JOHNSON, C. B. SPEROW, and G. A. MeLAREN

THE production of sweet sorghum for sirup in West Virginia is a specialized enterprise which, although important in a few areas, is conducted only on small acreages. Most of the finished sirup produced is consumed locally, although a small amount is marketed commercially. Since information on sweet sorghum culture ${ }^{1}$ and methods of preventing sugar crystallization had been requested by farmers of this State, a limited production performance study was begun in 1956 by the Department of Agronomy and Genetics at the Ohio Valley Sub-station at Point Pleasant.

Much of the sorgo sirup produced in West Virginia lacks consumer acceptance because of unsightly crystallization of sugars which occurs during storage. It has been reported by Walton, et al. (1938) that crystallization in sorgo sirup may result from either an excess of reducing sugars or sucrose. It is common knowledge in the field of cane sugar technology that crystallization can be prevented in high density sirups by attaining a sucrose to reducing sugar ratio of approximately one. The crystallization problem of sorgo sirups could be eliminated by producing sirups containing approximately equal percentages of sucrose and reducing sugar. This could be achieved through selection of sorgo varieties which contain the desired sucrose to reducing sugar ratio. One of the objectives of this investigation was to determine the sucrose and reducing sugar contents of six varieties of sorgo cane at different stages of maturity. A second objective involved determining the effect on the sugar composition of the juice, as the result of holding the harvested cane for 10 days before extracting the juice.

'Detailed information on the culture of sorgo for sirup production is presented in a U.S.D.A. bulletin by Stokes, et al. (1957). 


\section{Materials and Methods}

Sweet sorghum performance trials were conducted at the Ohio Valley Sub-station, Point Pleasant, in 1956, 1957, and 1958. Each year six varieties were tested. They were grown on a Wheeling fine sandy loam soil and check planted in rows spaced 42 inches apart. In 1956 and again in 1958 the plot size was $14 \times 42$ feet and included four rows. Thirty-five feet of the two center rows of each plot were harvested for yield. In 1957 a plot $14 \times 85$ feet was used with 75 feet of the two center rows harvested for yield. In all plots the varieties were planted thick and then thinned to three plants per hill. A randomized block design with four replications was used in all cases.

The trial was conducted each year on land that had been in alfalfa the previous year. Fertilizer applications consisted of 500 pounds per acre of 5-10-10 plowed down and 250 pounds applied in the row.

The weather conditions during the growing season of each of the three years varied considerably. In 1956 rainfall and temperature were average for the area; drought conditions prevailed in 1957, and in 1958 very high rainfall and lower than average temperatures occurred.

In 1956 and 1957 all of the plots were harvested when the heads of the sorgo had attained the soft-dough stage. All leaves were stripped from the stalks and the heads were removed just prior to cutting the cane. The cane was bundled, weighed, and taken to a local processing plant where the juice was extracted and processed in to sirup. Because this method did not give entirely reliable estimates of finished sirup yield and quality, it was discontinued in 1958. Instead, sirup yield and quality were determined by laboratory. analysis of the fresh juice. Preliminary analysis in 1957 had indicated that such a method was feasible.

The procedure followed in 1958 entailed three different harvesting treatments. In all cases the juice was extracted from a weighed sample of cane by means of a conventional cane mill. The three treatments were: (1) harvesting, extracting, and analyzing the juice of cane cut at the soft-dough stage; (2) harvesting at the soft-dough stage but extracting and analyzing the juice after a period of 10 days; and (3) harvesting, extracting, and analyzing the juice of plants cut 10 days after the soft-dough stage. A 10-pound sample of cane was used from each plot. The extracted juice was passed through a 20mesh screen to remove any coarse foreign material and weighed. Samples of sorgo juice were frozen immediately after extraction from the cane and kept frozen until taken out for analysis. 
The samples were not thawed for analysis, rather they were crushed in a hand-operated ice crusher. Fifty grams of the crushed sample was weighed on a torsion balance and immediately placed in $200 \mathrm{ml}$. of water containing $1 \mathrm{ml}$. of saturated neutral lead acetate. After addition of the lead aceate, which not only served as a clarifying agent but also inhibited plant or microbial enzyme activity, the mixture was made up to $500 \mathrm{ml}$. Solutions were permitted to stand overnight at room temperature in order to effect complete precipitation of any interfering colloids. The precipitate was removed by filtration, and excess lead was removed by means of potassium oxalate. Aliquots of the clarified, deleaded sugar solutions were analyzed for reducing sugars according to the method of Lane and Eynon, as described in the Association of Official Agricultural Chemists (1950). Sucrose was determined by difference after inversion with yeast invertase.

The sorgo juice samples were allowed to stand at room temperature for four hours before the percentage of soluble solids was determined on the supernatant. This percentage was determined by means of an Abbe refractometer equipped with a Brix scale. All percentages of soluble solids were reported as degrees Brix refractometer.

\section{Results and Discussion}

Results of these trials in terms of cane and finished sirup yields per acre for the years 1956, 1957, and 1958, are represented in Tables 1,2 , and 3 , respectively. The disease factor did not present problems in any of these years so no direct statements in this regard can be made. However, certain diseases do cause heavy losses in sorgo varieties from time to time, and are an ever-present threat to their production, since all commercial varieties are susceptible to one or more of the common sorgo diseases. Detailed information on sorgo diseases is given in U.S.D.A. Farmers' Bulletin 1959 (1944).

In 1956 the only data taken were yield of cane in tons per acre and approximate yield of finished sirup in gallons per acre. The data in Table 1 indicate that yields of both cane and sirup varied considerably among the varieties tested, with sirup yields ranging from very low to very high. Environmental conditions were quite favorable for plant growth in that year. As stated previously, the method used to determine sirup yields was not entirely satisfactory and thus sirup production per acre is given as an approximation. These figures could be either somewhat higher or lower than they are as given in the tables.

In 1957 a very dry growing season was experienced at the Ohio Valley Sub-station farm, and thus the results obtained were entirely 
Table 1. Sorgo Variety Trial, 1956

\begin{tabular}{|c|c|c|}
\hline Variety & $\begin{array}{l}\text { Yield Per Acre } \\
\text { (Pounds) }\end{array}$ & $\begin{array}{c}\text { Finished Sirup } \\
\text { (Gallons) }\end{array}$ \\
\hline Atlas _.-. & 16,560 & 66.7 \\
\hline Williams & 24,800 & 88.9 \\
\hline Sart & 25,400 & 88.9 \\
\hline Tracy & 19,400 & 133.3 \\
\hline Wiley & 18,380 & 222.3 \\
\hline Honey & 29,800 & 289.0 \\
\hline
\end{tabular}

Table 2. Sorgo Variety Trial, 1957

\begin{tabular}{l|c|c}
\hline Variety & $\begin{array}{c}\text { Yield Per Acre } \\
\text { (Pounds) }\end{array}$ & $\begin{array}{c}\text { Finished Sirup } \\
\text { (Gallons) }\end{array}$ \\
\hline Honey - & 7,912 & 21.0 \\
Sart & 11,678 & 31.0 \\
Wiley & 10,432 & 41.5 \\
Williams & 13,273 & 41.5 \\
Tracy & 14,020 & 46.7 \\
Sugar $---19,641$ & 62.0 \\
\hline
\end{tabular}

different from those of 1956. Cane and sirup yields (Table 2) were greatly reduced. In several cases stands were poor, and because of the drought conditions that prevailed during July and August the plants remained in a near dormant state. Then, in September, when adequate moisture became available, growth was resumed; however, the sorgo was killed by frost before it had reached the soft-dough stage of maturity, and thus yields were drastically reduced. The variety Sugar Drip produced considerably more sirup than any of of the others in this dry year. Honey, a variety that gave exceptionally high sirup yields in 1956 and 1958, produced very low cane and sirup yields in the dry year. Sirup yields were low for Sart and intermediate for Wiley, Williams, and Tracy under these same conditions.

The cane and sirup yields for the varieties tested in 1958 are given in Table 3. The finished sirup yields for this trial were calculated from cane and juice yields based on laboratory analysis and are designated as a sirup of 78 Brix (ref.). The amount of finished sirup produced per acre varied considerably among the varieties tested, but was generally quite high. Williams and Honey proved to be superior from the standpoint of both yield and quality of sirup, producing juices with suitable sucrose to reducing sugar ratios to prevent crystallization of the refined sirup (Table 2). Although the variety Sugar Drip produced a fairly high yield of finished sirup, its ratio 


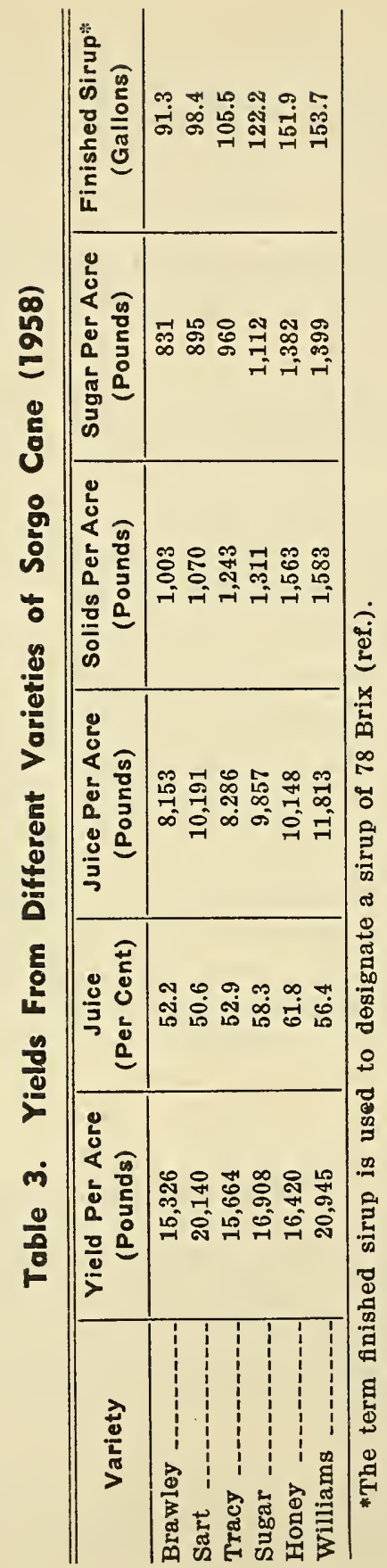


of sucrose to reducing sugar was completely out of balance, as was that of the other lower yielding varieties included in the trial. The sucrose content of Sart, Brawley, and Sugar Drip was too high to be certain that crystallization would not occur. Although partial inversion of sucrose from the juice of these sorgo varieties would yield a sirup not too prone to crystallization, such a step must be wellcontrolled and would increase the cost of production. The high reducing sugar content of juice extracted from the Tracy variety indicates that sirups produced from such juice would show crystallization of reducing sugars.

Cutting the cane 10 days after it reached the soft-dough stage did not markedly affect the ratio of sucrose to reducing sugar, but it did influence the percentage of total sugars in the juice (Table 4). There was a decrease in total sugars in the juice of all varieties except Tracy, which showed a slight increase in total sugars.

It may be noted at the bottom of Table 4 that holding cane for 10 days after harvesting resulted in complete inversion of the sucrose in the juice from all varieties except Brawley. Apparently all of the other varieties contained sufficient invertase to effect the inversion of sucrose to invert sugar (reducing sugars). These data certainly indicate that cane should be extracted immediately after it is cut, rather than held for several weeks before extraction. Althongh it is a common practice of many sorgo producers to hold cane after it is cut in hope that the resulting inversion will prevent crystallization, actually it appears to be responsible for most of the crystallization problems. There is no way of controlling inversion of sucrose by the invertase in the cane, hence a variety containing a high concentration of this enzyme will completely invert all of the sugar just as happened in five of the varieties used in this study.

\section{Literature Cited}

A.O.A.C. 1950. Methods of Analysis of the Association of Official Agricultural Chemists. Washington, D. C.

Lenkel, R. W., John H. Martin, and C. L. Leefebore. 1944. Sorghum Diseases and Their Control. Farmers' Bulletin No. 1959., U.S.D.A.

Stokes, I. E., O. H. Coleman, and Jack L. Dean. 1957. Culture of Sorgo for Sirup Production. Farmers' Bullet in No. 2100., U.S.D.A.

Walton, C. F., E. K. Ventre, and S. Bell. 1938. Farm Production of Sorgo Sirup. Farmers' Bulletin No. 1791., U.S.D.A. 


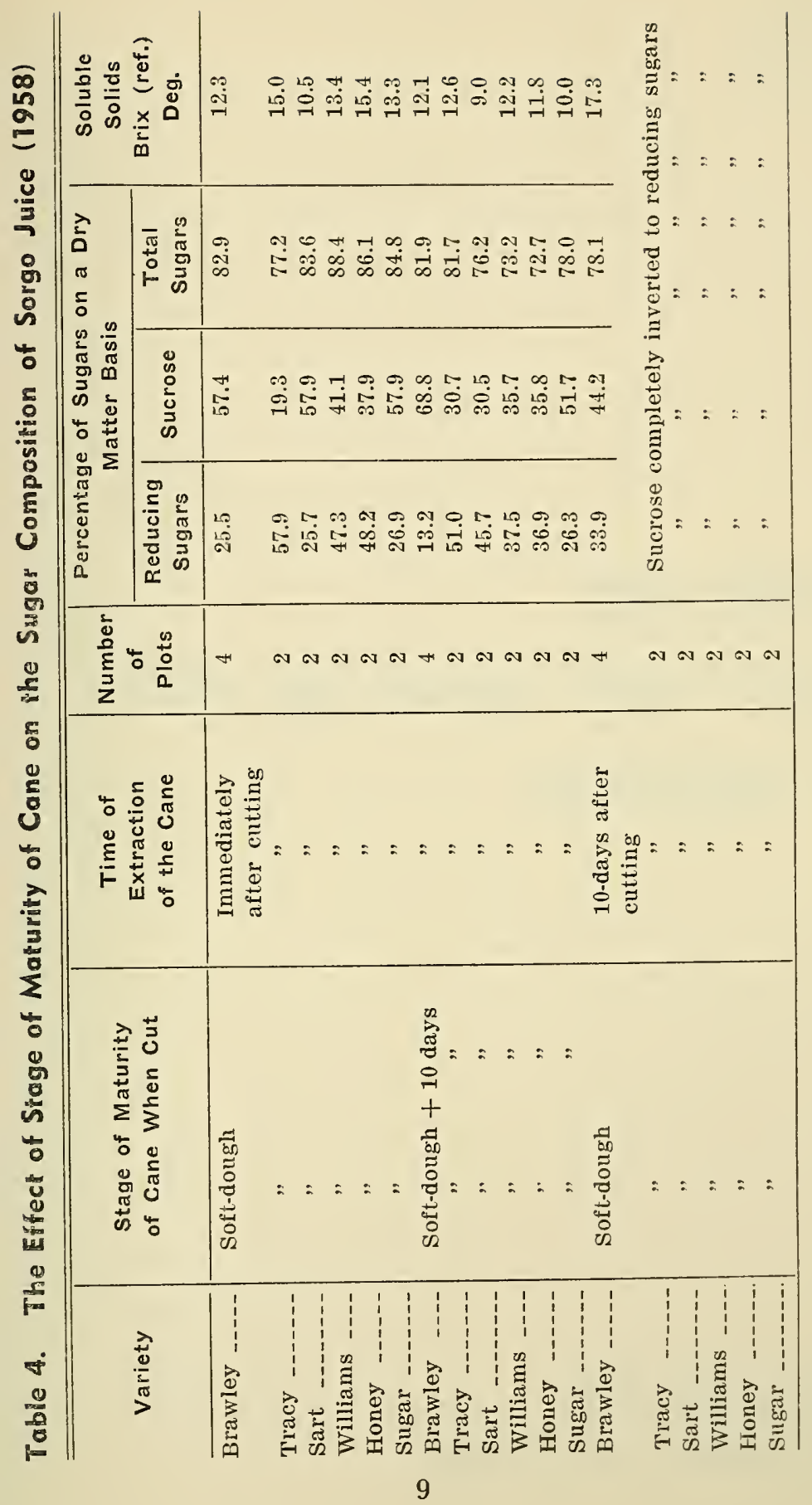


